\title{
Isolation and caracterisation of sodium monocarboxylate ixoside salt from the stem bark of Oxyanthus pallidus
}

\author{
Ignas Bertrand TIGOUFACK NZEDONG ${ }^{1}$, David NGNOKAM ${ }^{1 *}$, \\ Leon A. TAPONDJOU ${ }^{1}$, Dominique HARAKAT ${ }^{2}$ and Laurence VOUTQUENNE ${ }^{3}$ \\ ${ }^{1}$ Faculty of Science, Department of Chemistry, University of Dschang, P.O. Box 67. Dschang, Cameroon. \\ ${ }^{2}$ Service Commun d'Analyses, Institut de Chimie Moléculaire de Reims (ICMR), CNRS UMR 7312, Bat. 18 \\ B.P.1039, 51687 Reims Cedex2, France. \\ ${ }^{3}$ Groupe Isolement et Structure, Institut de Chimie Moléculaire de Reims (ICMR), CNRS UMR 7312, Bat. 18 \\ B.P.1039, 51687 Reims Cedex2, France. \\ *Corresponding author; E-mail: dngnokam@yahoo.fr; Tel. (237)96932925
}

\begin{abstract}
A sodium monocarboxylate ixoside salt(1) and four known compounds, ixoside (2), mannitol (3), uncargenine C (4) and oleanolic acid (5) have been isolated from the stem bark of Oxyanthus pallidus. Their structures were established on the basis of spectroscopic techniques.

(C) 2012 International Formulae Group. All rights reserved.
\end{abstract}

Keywords: Oxyanthus pallidus, Oxyanthus sankuruensis, Oxyanthus schubotzianus, Rubiaceae, iridoids, sodium monocarboxylate ixoside salt.

\section{INTRODUCTION}

Oxyanthus pallidus Hiern/Oxyanthus
sankuruensis De Kild/Oxyanthus
schubotzianus K. Krause (Rubiaceae) is a
small shrub widespread from Senegal to
Nigeria, and extending from Sudan to
Ethiopia (Hallé, 1970). Plants of the genus
Oxyanthus, occupy a prominent position in
traditional African medicine (Watt and
Breyer-Brandwijk, 1962; Bouquet, 1969;
Adjonohoun et al., 1988; Kawukpa and
Angoyo, 1994; Obijiofor, 2002; Chaaib,
2004). Our previous contribution reported the
isolation from the leaves of three new
cycloartane glycosides (Tigoufack et al.,
2010). In an extension of our studies, the methanol extract of the stem bark of Oxyanthus pallidus was examined for minor concentrations of sodium monocarboxylate ixoside salt (1).

\section{MATERIALS AND METHODS}

General experimental procedures

All melting points were recorded with a Reichter microscope and are uncorrected. IR spectra were recorded with a Shimadzu FTIR8400 spectrometer. ${ }^{1} \mathrm{H}$ NMR $(500 \mathrm{MHz})$ and ${ }^{13} \mathrm{C}$ NMR (125 MHz) spectra were recorded in $\mathrm{CD}_{3} \mathrm{OD}$ on a Bruker Avance DRX-500 spectrometer. Chemical shifts $(\delta)$ are reported in parts per million with solvent signals $\delta_{\mathrm{H}}$ 3.31 and $\delta_{\mathrm{C}} 49.1$ as references, while the 
coupling constants $(J)$ are given in Hertz. HRESI-MS experiments were performed using a Micromass Q-TOF micro instrument (Manchester, UK) with an electrospray source. Column chromatography was run on Merck silica gel 60 and Sephadex LH-20 while TLC was carried out on silica gel $\mathrm{GF}_{254}$ precoated plates with detection accomplished by spraying with $50 \% \mathrm{H}_{2} \mathrm{SO}_{4}$ followed by heating at $100{ }^{\circ} \mathrm{C}$.

\section{Plant material}

Stem barks of Oxyanthus pallidus were collected in the city of Dschang, Cameroon, in March 2010 and identified by Mr. Victor Nana, a botanist of the National Herbarium of Cameroon (Yaoundé) where a voucher specimen $\left(n^{\circ} 7335 / \mathrm{SFR} / \mathrm{CAM}\right)$ was deposited.

\section{Extraction and isolation}

The air-dried and finely powdered material $(4.5 \mathrm{~kg})$ was extracted with $\mathrm{MeOH}$ (10 1) in a glass tank at room temperature. After complete removal of solvent by vacuum evaporation, a dark residue $(132 \mathrm{~g})$ was obtained. Part of this, (52 g) was fractionated, on silica gel (40-63 $\mu \mathrm{m}, 98 \mathrm{~g})$ column chromatography, eluted with ethyl acetate, followed by a mixture of ethyl acetate and 10$70 \%$ of $\mathrm{MeOH}$, yielded five main fractions (A-E). Silica gel column chromatography of the ethyl acetate fractions, A ( $2 \mathrm{~g})$, and B (5.1 g) using hexane-EtOAc (1:1) for $\mathrm{A}$ and hexane-EtOAc $(2: 8)$ for $\mathrm{B}$ yielded oleanolic acid (1.1 g) (5) and uncargenine C (10 mg) (4) respectively. Fraction $\mathrm{C}(357.3 \mathrm{mg})$, was obtained with EtOAc-MeOH (8:2); when the mixture of solvents was distilled off, a precipitate was formed that crystallized in ethyl acetate affording $43.7 \mathrm{mg}$ of mannitol (3) after vacuum filtration. Fraction D $(2.4 \mathrm{~g})$ obtained with a mixture of EtOAc-MeOH (7:3) was purified over Sephadex LH-20 gel using $\mathrm{MeOH}$ followed by silica gel column chromatography using the mixture of EtOAc-
MeOH- $\mathrm{H}_{2} \mathrm{O}(8: 1: 1)$ to yield compound 2 (30.8 $\mathrm{mg})$. Sub-fraction D-3 (80 mg), was purified over silica gel column chromatography, using the mixture of EtOAc-MeOH- $\mathrm{H}_{2} \mathrm{O}(8: 1: 1)$ to yield compound 1 (50 $\mathrm{mg}$ ).

\section{Compound 1}

$[\alpha]_{\mathrm{D}}^{25}+24^{\circ}\left(\mathrm{CH}_{3} \mathrm{OH}, c 0.308 \times 10^{-2}\right)$; IR $v_{\max }$ $(\mathrm{NaCl}) \mathrm{cm}^{-1}: 1726(\mathrm{C}=\mathrm{O}) ; 1271(\mathrm{C}-\mathrm{O}) ;{ }^{1} \mathrm{H}$ and ${ }^{13} \mathrm{C} \quad\left(\mathrm{CD}_{3} \mathrm{OD}\right)$ : Table 1; HR-ESI-MS (negative-ion mode) $\mathrm{m} / z \quad 387.0927 \quad[\mathrm{M}-\mathrm{Na}]^{-}$ (calculated for $\mathrm{C}_{16} \mathrm{H}_{16} \mathrm{O}_{11}: 387.0931$ ).

\section{Determination of the absolute configuration of the glucose moiety in 1}

$20 \mathrm{mg}$ of compound $\mathbf{1}$ were refluxed with $10 \% \mathrm{HCl}(10 \mathrm{ml})$ at $80{ }^{\circ} \mathrm{C}$ for $3 \mathrm{~h}$. The reaction mixture was extracted with EtOAc, and the aqueous phase was concentrated under reduced pressure to yield D-glucose $(4.8 \mathrm{mg})$, identified on TLC by comparison with an authentic sample. Its relative configuration was determined by measurement of the optical rotation value, $[\alpha]^{23}{ }_{D}+56.2^{\circ}\left(\mathrm{H}_{2} \mathrm{O}, c\right.$ 0.973).

\section{RESULTS AND DISCUSSION}

Compound 1, $\mathrm{C}_{16} \mathrm{H}_{19} \mathrm{O}_{11} \mathrm{Na}$, which carbonized to a cinder without melting, was obtained as a black powder with optical rotation $[\alpha]_{\mathrm{D}}{ }^{25}+24^{\circ}\left(\mathrm{CH}_{3} \mathrm{OH}, c 0.308 \times 10^{-2}\right)$. HR-ESI-MS, in negative-ion mode, showed a molecular ion peak at $\mathrm{m} / z 387.0927$ [M-Na] in agreement with the molecular formula $\mathrm{C}_{16} \mathrm{H}_{19} \mathrm{O}_{11}$. The presence of the sodium ion in this molecular formula was deduced from the HR-ESI-MS in positive-ion mode. The IR spectrum indicated the presence of hydroxyl group (3500-3360 $\left.\mathrm{cm}^{-1}\right)$, carbonyl $\left(1726 \mathrm{~cm}^{-1}\right)$, and carbon carbon double bond $\left(1645 \mathrm{~cm}^{-1}\right)$. The ${ }^{1} \mathrm{H}$ NMR spectrum (Table 1) showed characteristic signals of iridoid glycoside type of ixoside (Guarnaccia et al., 1972; Yoshio et al., 1975; Luciano et al., 2010). Indeed, two allylic protons were observed at $\delta 2.35(1 \mathrm{H}$, ddd, $J=17.5,8.2$ and $2.5 \mathrm{~Hz}, \mathrm{H}-6 \beta), 2.87$ 
(1H, ddd, $J=17.5,8.2$ and $2.5 \mathrm{~Hz}, \mathrm{H}-6 \alpha)$ ] and two vinylic protons at $\delta 6.52(1 \mathrm{H}$, brd, $J=1.6$ $\mathrm{Hz}, \mathrm{H}-7), 7.34$ (1H, s, H-3). Signals observed at $\delta 3.17(1 \mathrm{H}, \mathrm{m}, \mathrm{H}-9)$ and $\delta 3.32(1 \mathrm{H}, \mathrm{m}, \mathrm{H}-$ 5)] were attributed to the iridan methine groups. The signal observed at $\delta 5.62(1 \mathrm{H}, \mathrm{d}$, $J=4.7 \mathrm{~Hz}, \mathrm{H}-1$ ) was attributed to the iridan acetal group due to the downfield shift. Remaining protons observed between $\delta$ 4.633.30 are those of a $\beta$-glucopyranosyl moiety after analysing its Cosy spectrum (Figure 1). Acid hydrolysis of $\mathbf{1}$ afforded D-glucose, which was identified on TLC by comparison with an authentic sample, and the configuration was determined by measurement of the optical rotation value. The 1,2 diaxial coupling of anomeric proton (H-1') at $\delta 4.63(\mathrm{~d}, J=7.8 \mathrm{~Hz})$ indicated the $\beta$ configuration of the glucose unit. Compound 1 was clarified by HMBC experiments. Indeed, the connectivity of the $\beta$-Dglucopyranosyl moiety was elucidated on the basis of HMBC correlations, observed between $\mathrm{H}-1$ ' $(\delta 4.63, \mathrm{~d}, J=7.8 \mathrm{~Hz})$ and $\mathrm{C}-1$ $(\delta$ 95.1), and between $\mathrm{H}-1$ ( $\delta$ 5.62) and C-1' $(\delta$ 98.6), as shown on Figure 2. The ${ }^{13} \mathrm{C}$ NMR spectrum of 1 was almost superimposable on that of ixoside (2) (Table 1), except for the NMR data of carbons C-6, C-7, C-8, C-9 and C-10. Specifically, the significant upfield shift ( $\delta 138.8$ from 146.6 of C-7), and downfield shift ( $\delta 38.7$ from 33.6 of C-6, 141.0 from 135.0 of C-8 and 171.9 from 166.7 of C-10) indicated that the sodium carboxylate group was located at the $\mathrm{C}-8$ position. This assumption was confirmed by an HMBC correlation observed between $\mathrm{H}-7$ and $\mathrm{C}-10$ (Figure 2). The two carbonyl groups, C-10 and $\mathrm{C}-11$ of 1 which both appeared at the same value of $\delta 171.9 \mathrm{ppm}$, were clearly observed at $\delta 166.7$ and 169.2 for C-10 and C11 respectively, after adding a drop of TFA in the nmr tube. The relative stereostructure of $\mathbf{1}$ was established by NOESY experiment; the strong NOE correlation observed between H-9 at $\delta 3.17$ and $\mathrm{H}-5$ at $\delta 3.32$ (Figure 3) suggested their $\beta$-orientation (Guarnaccia et al., 1972; Yoshio et al., 1975; Kanchanapoom et al., 2002; Luciano et al., 2010). The absence of NOE correlation between $\mathrm{H}-1$ at $\delta$ 5.62 and $\mathrm{H}-9$ at $\delta 3.17$; $\mathrm{H}-5$ at $\delta 3.32$, confirmed the $\alpha$-orientation of $\mathrm{H}-1$. All these information allowed us to suggest that, compound 1 was elucidated to be a sodium monocarboxylate ixoside salt.

Structures (2-5) (Figure 4) were determined by means of Co TLC, spectroscopic data, and by comparative analysis of physical and spectral data with those in the literature (Takeda et al., 1975; Pouchet et al., 1970; Yang et al., 1995; Meicai, 2008). TLC retention time, obtained for compounds $\mathbf{1}$ and $\mathbf{2}$ in the mixture EtOAc$\mathrm{MeOH}-\mathrm{H}_{2} \mathrm{O} \quad(7: 2: 1)$ are 0.43 and 0.28 respectively.

Table 1: ${ }^{1} \mathrm{H}$ and ${ }^{13} \mathrm{C}$ NMR data of compounds $\mathbf{1}$ and $\mathbf{2}$ in $\mathrm{CD}_{3} \mathrm{OD}$.

\begin{tabular}{llcccc}
\hline $\mathrm{H}$ & $\mathbf{1}$ & $\mathbf{2}$ & $\mathrm{C}$ & $\mathbf{1}$ & $\mathbf{2}$ \\
\hline position & $\delta{ }^{1} \mathrm{H}($ mult., $J(\mathrm{~Hz}))$ & $\delta{ }^{1} \mathrm{H}($ mult., $J(\mathrm{~Hz}))$ & position & $\delta{ }^{13} \mathrm{C}$ & $\delta{ }^{13} \mathrm{C}$ \\
1 & $5.62(1 \mathrm{H}, \mathrm{d}, 4.7)$ & $5.70(1 \mathrm{H}, \mathrm{d}, 5.0)$ & 1 & 95.1 & 94.9 \\
3 & $7.34(1 \mathrm{H}, \mathrm{s})$ & $7.51(1 \mathrm{H}, \mathrm{s})$ & 3 & 149.4 & 152.1 \\
& & & 4 & 114.7 & 111.1 \\
5 & $3.32(1 \mathrm{H}, \mathrm{m})$ & $3.33(1 \mathrm{H}, \mathrm{m})$ & 5 & 34.3 & 33.6 \\
$6 \alpha$ & $2.87(1 \mathrm{H}, \mathrm{ddd}, 17.5,8.2,2.5)$ & $2.94(1 \mathrm{H}, \mathrm{ddd}, 17.6,8.0,2.3)$ & 6 & 38.7 & 33.8 \\
$6 \beta$ & $2.35(1 \mathrm{H}, \mathrm{ddd}, 17.5,8.2,2.5)$ & $2.47(1 \mathrm{H}, \mathrm{ddd}, 17.6,8.0,2.3)$ & & & \\
7 & $6.52(1 \mathrm{H}$, brd, 1.6$)$ & $6.92(1 \mathrm{H}, \mathrm{brd}, 1.7)$ & 7 & 138.8 & 146.6 \\
\hline \multicolumn{2}{r}{} & 7008 & & &
\end{tabular}




\begin{tabular}{llcccc}
\hline & & & 8 & 141.0 & 135.0 \\
9 & $3.17(1 \mathrm{H}, \mathrm{m})$ & $3.22(1 \mathrm{H}, \mathrm{m})$ & 9 & 46.7 & 46.0 \\
& & & 10 & 171.9 & 166.7 \\
& & & 11 & 171.9 & 169.1 \\
Glc-1' $^{\prime}$ & $4.63(1 \mathrm{H}, \mathrm{d}, 7.8)$ & $4.65(1 \mathrm{H}, \mathrm{d}, 7.9)$ & 1, & 98.6 & 98.9 \\
$2^{\prime}$ & $3.23(1 \mathrm{H}, \mathrm{dd}, 8.6,7.8)$ & $3.22(1 \mathrm{H}, \mathrm{dd}, 8.5,7.9)$ & 2, & 73.2 & 73.2 \\
$3^{\prime}$ & $3.38(1 \mathrm{H}, \mathrm{dd}, 8.9,8.6)$ & $3.36(1 \mathrm{H}, \mathrm{dd}, 8.9,8.5)$ & 3, & 76.3 & 76.4 \\
$4^{\prime}$ & $3.31(1 \mathrm{H}, \mathrm{dd}, 8.9,8.5)$ & $3.32(1 \mathrm{H}, \mathrm{dd}, 8.9,8.6)$ & 4 & 70.1 & 70.0 \\
$5^{\prime}$ & $3.30(1 \mathrm{H}, \mathrm{m})$ & $3.29(1 \mathrm{H}, \mathrm{m})$ & 5, & 76.7 & 76.8 \\
$6^{\prime} \alpha$ & $3.67(1 \mathrm{H}, \mathrm{dd}, 12.2,2.2)$ & $3.70(1 \mathrm{H}, \mathrm{dd}, 12.1,2.1)$ & 6 & 61.3 & 61.2 \\
$6^{\prime} \beta$ & $3.85(1 \mathrm{H}, \mathrm{dd}, 12.2,2.2)$ & $3.88(1 \mathrm{H}, \mathrm{dd}, 12.1,2.1)$ & & & \\
\hline
\end{tabular}

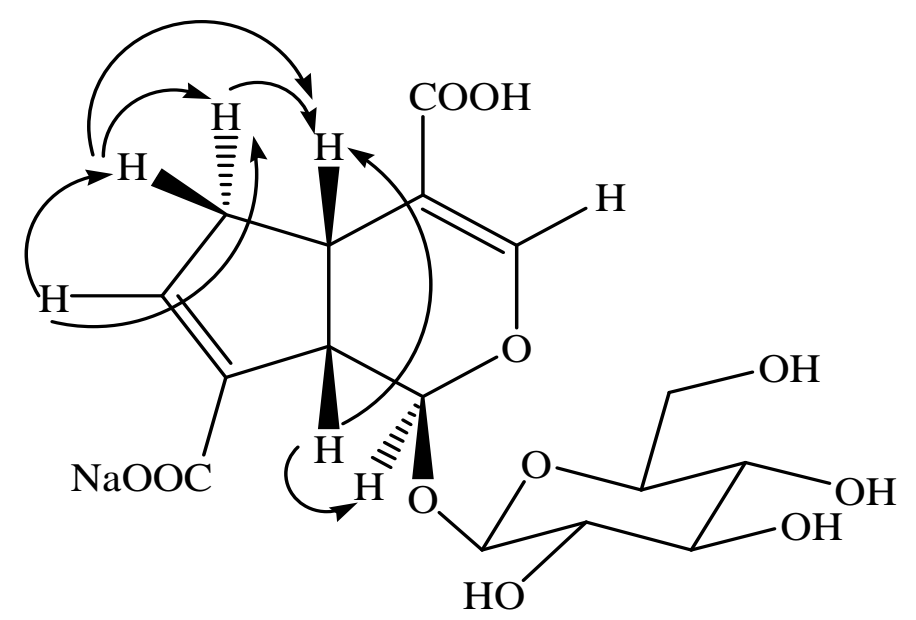

Figure 1: ${ }^{1} \mathrm{H}-{ }^{1} \mathrm{H}$ COSY Correlations of compound $\mathbf{1}$

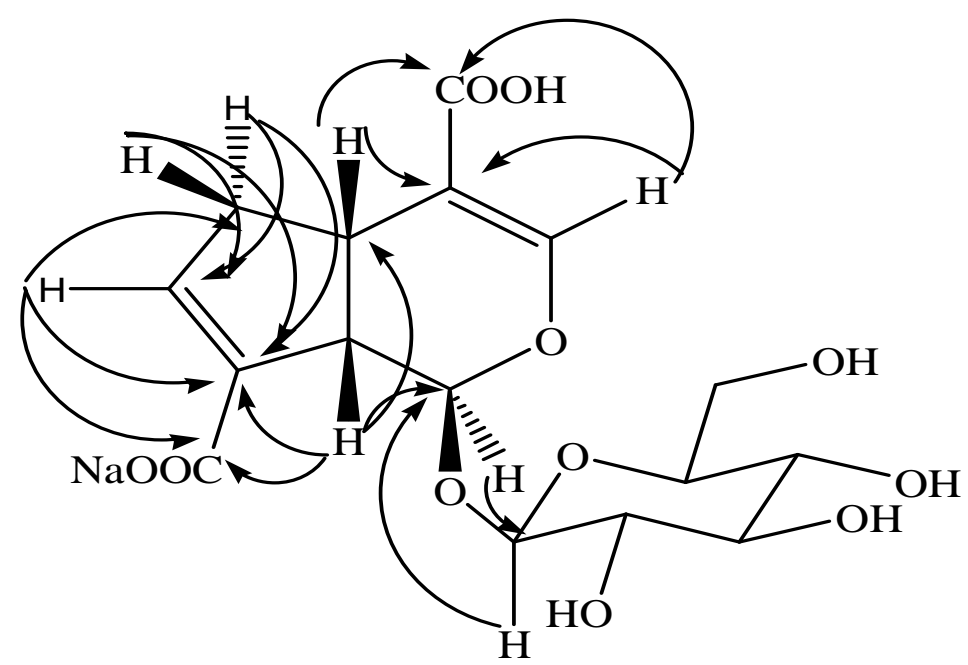

Figure 2: HMBC Correlations of compound 1 


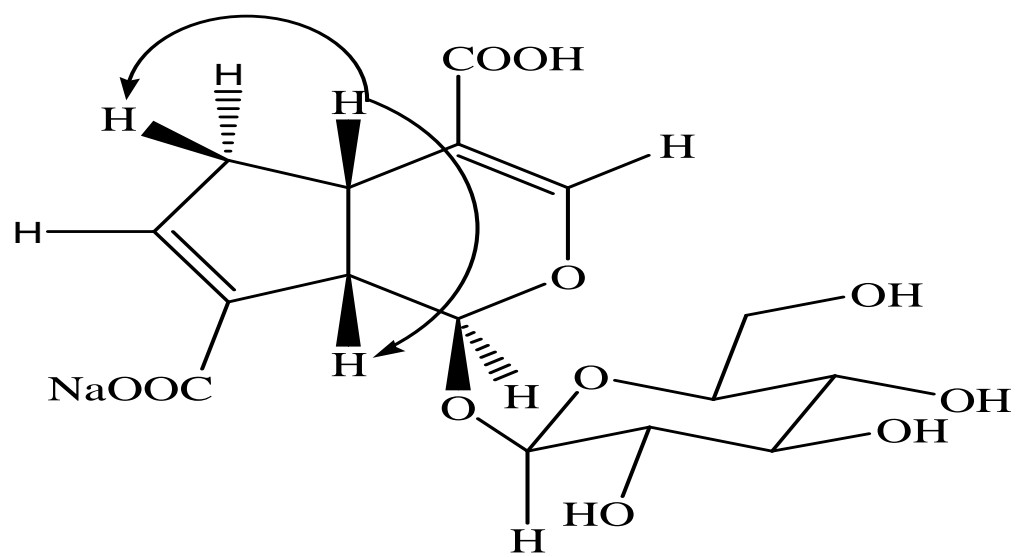

Figure 3: NOE Correlations of compound 1
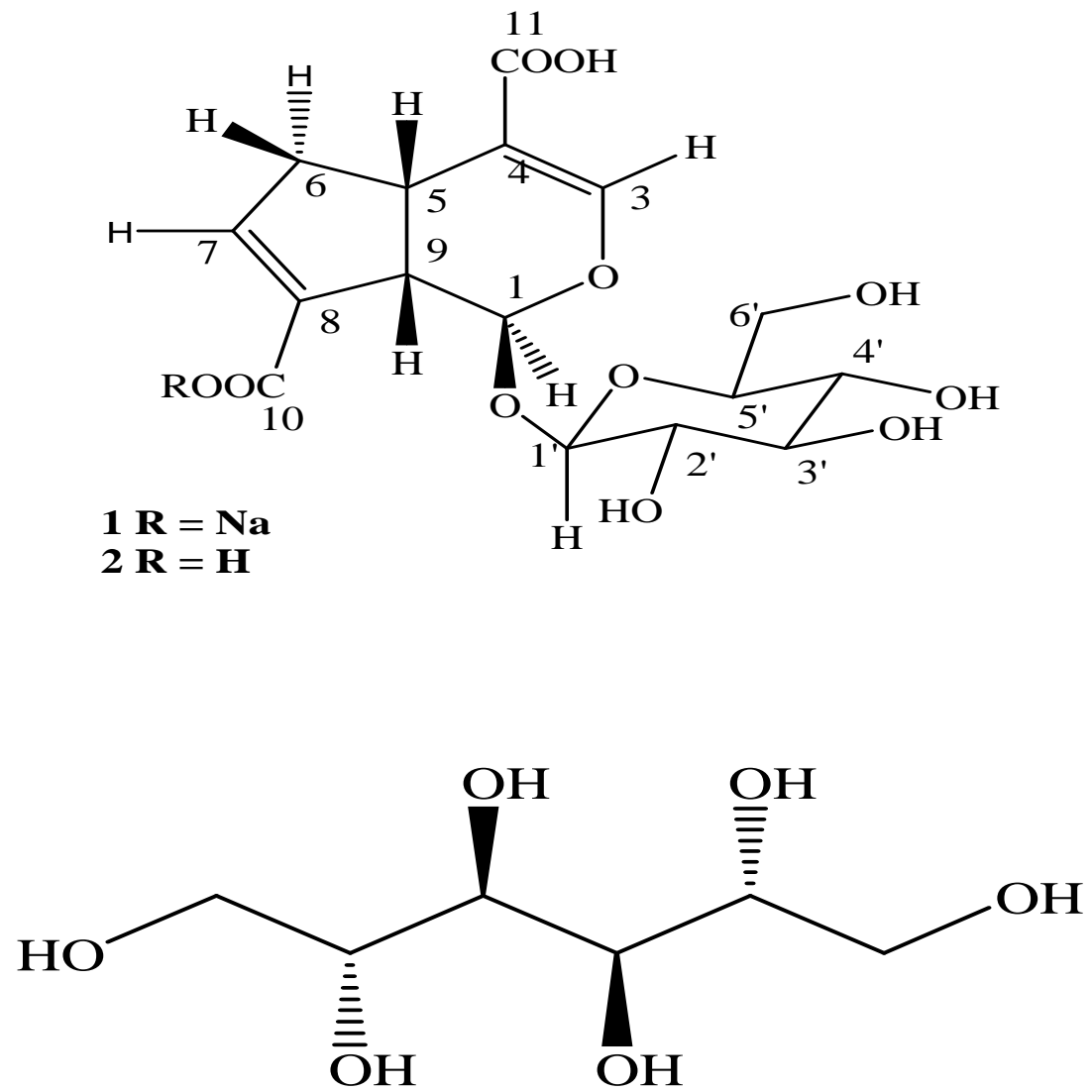

3 



Figure 4: Structures of isolated compounds.

\section{REFERENCES}

Adjanohoun EJ, Ahyi AMR, Ake, AL, Baniakina J, Chinon P, Cusset G, Doulou V, Enzanza A, Eymé J, Goudoté E, Keita A, Mbemba C, Mollet J, Moutsaboté J, Mpati J, Sita P. 1988. Contribution aux Etudes Ethnobotaniques et Floristiques en République Populaire du Congo. Agence de Coopération Culturelle et Technique: Paris; 605p.

Bouquet A. 1969. Féticheurs et Médecine Traditionnelle du Congo (Brazzaville).
Travaux et Documents de l'ORSTOM, Paris 36; 128p.

Chaaib KF. 2004. Investigation phytochimique d'une brosse à dents africaine, Zanthoxylum zanthoxylö̈des Lam. (Zepernick et Timler). (Syn. Fagara zanthoxylö̈des) (Rutaceae). Thèse de Doctorat en Pharmacie, Universtié de Lausanne, Lausanne, $211 \mathrm{p}$.

Guarnaccia R, Madyastha KM, Tegtmeyer E, Coscia CJ. 1972. Geniposidic acid, a glucoside from Genipa americana. Tetrahedron Letters, 50: 5125-5127. 
Hallé N. 1970. Flore du Gabon. Muséum National d'Histoire Naturelle, Laboratoire de phanérogamie : Paris 17; 335 p.

Obijiofor C. 2002. Integrating African ethnomedicine into primary healthcare: A framework for South-Eastern Nigeria. In Ethnomedicine and Drug Discovery, Iwu MM, Wootton JC (eds). Elsevier Science B.V.: Amsterdam; 71-79.

Kawukpa UU, Angoyo MM. 1994. Plantes utiles chez les Batiabetuwa de l'île de Mbie, Kisangani, Zaïre. African Study Monograph., 15: 49-68.

Kanchanapoom T, Kasai R, Yamasaki K. 2002. Iridoidglucosides from Thunbergia laurifolia. Phytochemistry., 60: 769-771.

Luciano JHS, Lima MAS, Silveira ER, Vasconcelos IM, Fernandes GS, Souza EB. 2010. Antifungal iridoids, triterpenes and phenol compounds from Alibertia myrciifolia Sprunge (Ex. Schum). Quimica Nova., 33: 292-294.

Meicai D. 2008. Studies on the chemical constituents of Uncariarhyncophylla ligulariafischeri. Master of Pharmaceutical Science, Chengdu
Institute of Biology, Chinese Academy of Sciences: China; p. 101.

Pouchert CJ, Behnke J. 1993. The Aldrich Library of ${ }^{13} \mathrm{C}$ and ${ }^{1} \mathrm{H}$ FT NMR Spectra. Aldrich Chemical Company: Milwakee; $4300 \mathrm{p}$.

Takeda Y, Nishimura H, Inouye H. 1975. Two new iridoid glucosides from ixora chinensis. Phytochemistry, 14: $2647-$ 2650.

Tigoufack NIB, Ngnokam D, Tapondjou AL, Harakat D, Voutquenne L. 2010. Cycloartane glycosides from leaves of Oxyanthus pallidus. Phytochemistry, 71: 2182-2186.

Watt JM, Breyer-Brandwijk MG. 1962. Medicinal and Poisonous Plants of Southern and Eastern Africa. E\&S Livingstone: Edinburg; 1460 p.

Yang CJ, Zhang J, Wu DG. 1995. Triterpenoids from Uncaria Rhynchophylla. Acta Metallurgica Sinica, 17: $1-3$.

Yoshio T, Hiroshi N, Hiroyuki I. 1975. Two iridoid glucosides from Ixora chinensis. Phytochemistry, 14: 2647-2650. 